\title{
What Sustains a Fulfilling Life in Education?
}

\author{
Jonathan M. Barnes \\ Correspondence: Jonathan M. Barnes, Faculty of Education, Canterbury Christ Church University, UK. E-mail: \\ jonathan.barnes@canterbury.ac.uk
}

Received: April 19, 2013 Accepted: May 2, 2013 Available online: May 19, 2013

doi:10.11114/jets.v1i2.144

URL: http://dx.doi.org/10.11114/jets.v1i2.144

\begin{abstract}
Resilience is essential to the good teacher. This paper summarises research on factors that have sustained one life in education and compares them with narratives from nine other long-serving and fulfilled teachers. It identifies some elements that build teacher resilience and discusses how this knowledge might apply to teacher education and the school experience of children. An original method of auto-ethnography is used to discover sources of the personal values, attitudes, experiences and passions that contribute to resilience. An interpretivist paradigm and multiple perspectives are argued as necessary to discover what builds, preserves and strengthens the ability to withstand the multiple and continuous challenges of the teaching life.

The literature review re-analysis writings that directly influenced a single life. Other auto-ethnographic sources include six contrasting personal autobiographies, diaries, letters and transcribed biographical conversations with nine close friends in teaching. The research suggests that teacher resilience is associated with (a) a work-life closely aligned to personal values, (b) plentiful opportunities to develop friendships, and (c) frequent chances to use lifelong interests in creative contexts.

The process of research changed the researcher's practice in education. A sample of four teacher education projects founded on the research conclusions, provide evidence for its recommendations: that autobiographical and biographical activity, creative explorations of lifelong interests and personal values should be part of all teacher education programmes. Incorporating these recommendations would, it is claimed, widen inclusion and directly benefit the lives and learning of children.
\end{abstract}

Keywords: auto-ethnography, biography, children, creativity, development, friendship, values, resilience, teacher education

\section{Introduction}

Building resilient individuals and communities is a common theme in austere times. Resilient teachers are an important part of every community. If schools are to help create a happy present and sustainable future for children, their teachers should be confident, emotionally intelligent, flexible, healthy, optimistic, positive people - but the evidence on such resilience is worrying. Up to half the newly qualified teachers in the UK leave the profession within five years (Guardian, 2010, 2012) and record numbers of teachers are taking or considering early retirement (Independent on Sunday, 2012). In the United States similarly, teacher job satisfaction has fallen by $23 \%$ in just four years (Metlife, 2013). Reasons given for teacher dissatisfaction include: lack of support, increasing complexity, discipline problems, pension changes and declining resources. Teachers and education professionals suffer amongst the highest levels of stress-related illness in the UK (Health and Safety Executive, 2013) resulting in great personal unhappiness and increasing public expense. As years of press and government criticism demoralise many, the pace of social and technological change means that teachers play important and increasingly complex roles in children's lives. Cultivating qualities to help sustain the mental health of teachers during a long professional life might therefore be expected to be central to teacher education. They are not. Under pressure to deliver 'the standards' (DfE, 2012) or higher national rankings in Programme for International Student Assessment (PISA) scales, teacher education courses in England devote very little time to developing positive, sustainable and moral attitudes towards self and teaching, and even less towards helping trainees mature as individuals. Whilst primary education researchers, (e.g. Rose, 2008 Alexander, 2010) highlight pupil resilience in curriculum proposals, little is said in the UK or US about teacher resilience. This paper tracks attempts to discover what might help sustain teachers in leading a positive lifetime in education. 
Investigating resilience involves searching beneath the selves we habitually present to the world. Auto-ethnographic and ethnographic research methods are used to elucidate both the sources of teacher resilience and its importance. The main research question is, 'What relationships are there between experience, values, beliefs, educational approaches and teacher resilience?' A subsidiary question asks, 'What are the implications of such research for the lives and learning of children?'

For me, answering these questions involves systematic examination of self-told narratives and those of nine teacher-friends, uncovering the motives, values, interests and approaches we claim have sustained us. A review of the unique combination of books that shaped my personality, fed values, habits of thought and led to action, replaces the traditional literature review

\section{Literature: Words That Set and Bolstered Values}

Some lives can be guessed at from the books read in them. Between 1958 when I was seven and 1962 when I left primary school, Enid Blyton's middle class, moral adventures, a range of righteous 'children's classics,' much of the Bible, and lots of abridged Dickens shaped me. In secondary school Bible study continued, but also real Dickens, Hardy and later Lawrence, the 'war poets' and John Lennon reflected or directed my adolescent searching and helped consolidate already cherished values. Joyce, Gosse, Orwell and Thomas recommended as First Year, Initial Teacher Education (ITE) literature were read by a young adult mind already partly 'made up'. I entered ITE in 1969 fascinated by the challenges of a youth culture that contradicted old certainties. In the early 1970s lyrics like, 'Give Peace a chance', and 'All you need is love,' anti aggression concepts of 'flower power', and hopes of an, 'Age of Aquarius' led me towards what I saw as a more liberated world. The optimistic, questioning and idealistic character of my peers defined my choices of educational reading. The gentle practicality of Plowden (1967), Isaacs (1932) and Montessori (1972) matched naïve beliefs in kindness, sensitivity and democracy. Dewey (1934) gave substance to my preference for the arts. Grand theories from Piaget (outlined in Beard, 1969), Adler (1964), Bowlby (1958), Bruner (1968) and Vygotsky (1962) deepened my thinking along a trajectory already established by experience and beliefs.

Whilst Freud's emphasis on death, conflict and sex discomforted me, Jung (1963) appealed with his incorporation of the spiritual and mysterious. A religious young adult, I easily accommodated Jung's assertion that '... it is not the universal and the regular that characterise the individual, but rather the unique,' (1963, p. 5) within my worldview. Being drawn to friendships with my immigrant neighbours in south London and loving cathedrals and museums, Jung's concept of a 'universal unconscious' fitted my belief in the possibilities of communication across time and culture. I found Teilhard de Chardin (1959) and Buber (1971) comfortable because they placed relationships, values and science within a religious and hopeful context. A theistic viewpoint also drew me to Polanyi (1967) who argued that tacit knowledge, and (what I saw as 'God-given') intuition, underpinned scientific decisions just as it does creative acts. Polanyi used a familiar vocabulary when he described personal, felt knowledge as motivated by 'passions', 'commitments' and values. Fromm's (1956) humanistic emphasis on love, care, responsibility and respect overlapped with the faith I professed. The culture surrounding me, and the academic literature that supported it, ensured that ideals of love, mutual responsibility, deep relationships, hope and common purpose seemed achievable. Returning to these books for this research, I newly recognised the cultural assumptions on which they were based. Like me at the time, most of these writers seem too sure of what was right and true.

The foundations of my security were shaken in 1972 by another book. Berger and Luckman's, 'The Social Construction of Reality' (1967) persuaded me that nothing seen, felt or believed was absolute. God was a cultural phenomenon, 'reality' an accident of place, time, socialisation, surroundings and interests. The profession I was about to enter became a 'secondary socialisation' (after the primary one of family) in which children were simply taught the 'realities' of their culture rather than given the liberation I had experienced. Berger and Luckman's view oversimplified the role of teachers, assuming one model for western education, and threw my belief in vocation, faith, love, beauty and joy into confusion.

My ITE course required readings of Freud, Marx, Weber and Durkheim. Their explicit and humanistic values activated in the work of Freire, (1970), Neill, (1970) and Illich (1971) challenged me further to live out my remaining ideals. The only obstacle was my reflex respect for authority exposed by Freud (1961).

There were more cosy written worlds. Rogers' (1967) language - 'clients', 'unconditional positive regard', 'congruence' and 'empathy' quickly transferred to my own educational philosophy. The search for meaning described by Frankl (1959) captured my religious beliefs and widened them. By the end of my teacher education 'liberal' principles, founded on my conception of love guided me. I volunteered to teach in Africa, fully expecting enlightenment from new and exciting relationships with people beyond my culture and calling myself a 'Christian socialist', with Jung and Tolstoy (1966) in my luggage. 
My beliefs changed within months of arriving in Kenya. There I met atheists, Muslims, animists and Sikhs often seeming more admirable than the Christian missionaries I encountered. The books they wrote, read or starred in (Nyrere, 1971; Freire, 1972; Ngugi, 1967; Achebe, 1957; Turnbull, 1972) sought meaning in politics, confrontation and questioning and but also extended values like hope, communication, fairness, and love. These authors inspired and discomforted me with their certainty and shamed me for my conservatism. These coexisting, but conflicting layers of personal reality only became clear on revisiting the literature of my early twenties.

After Kenya 'academic' reading stopped for 25 years. I was a busy classroom teacher in secondary and primary schools, an inveterate traveller and eventually a head teacher with, 'no time for theory'. Holiday reading consisted of Conrad, Tolstoy, Dostoyevsky, Gaskell, with an African admixture contributed by Van der Post. They developed familiar themes through their opposites - love versus disappointment, joy and sadness, truth and lies, hope and despair, social justice and deference, communication and obfuscation, freedom and bondage. Re-acquaintance for this research showed how these authors overplayed the distinctiveness' of their character, perhaps weakening their contribution, but I freshly appreciated their role in articulating the values that underpinned my resilience as I faced values-conflicts in difficult schools and target-bound authorities.

Entering ITE at 50 years of age necessitated a return to theory. In my absence, writers and researchers (usually around my age) had been gathering evidence for the ideals of my youth. Creativity, a lifelong interest of mine, was explored by Sternberg $(1997,1999)$ and my love for communication, inter-disciplinarity and wordless ways of knowing was given weight by Gardner's (1993) theory of Multiple Intelligences. Czikszentmihalyi's 'flow' theory (2002) accurately described my passion for the arts and Entwhistle, (2000), confirmed my experience of young people's learning. When Seligman highlighted 'learned optimism', and 'authentic happiness' (2004) or Fredrickson focussed on the health and social benefits of positive emotions $(2004,2009)$ my fundamental values seemed vindicated. What is considered positive however, differs from person to person. Whilst positivity, happiness and optimism are contested terms, my experience in many cultures demonstrated that most are able to recognise and grade their own happiness. Encounters in schools across the world suggested that despite variations in their precise qualities there are strong overlaps in concepts of friendship, kindness, love, peace, justice and hope. In my frequent meetings with people with whom I shared no verbal or cultural language, the facial and bodily characteristics of positivity, were readable with considerable accuracy, confirming Ekman's research, (2004).

Memories of Bowlby's, attachment theory (1988, re-visited by Schore, 2003), LeDoux' work on emotions (1999, 2002) and Damasio's on joy (2003), introduced me to neuroscientific research in education. These writers claimed that joy or the positive state sometimes described as 'well-being' are optimal conditions of the human mind and body. Their work lent a veneer of authority or 'objectivity' to my experience that positivity helped learning, though clearly these writers are as much creatures of their own time as I am.

Finally, Hicks, (2006) and Scoffham (2010) among others reminded me how much places had silently stimulated and extended my own being. I recognised how cathedrals, museums, mountain-scapes, fens, deserts and rainforests, had also invoked and encapsulated the guiding values that I continue to share with children and colleagues.

A journey through the books that shaped my life revealed their importance in forming, preserving, developing and capitalising on values born in childhood. The relationships between these values and any resilience I have shown, forms the bulk of this paper. Reviewing the literary influences on my sense of empowerment alerted me to assumptions similar to mine and demonstrated both the consistencies and complexities of the human mind. Theory cannot capture the uniqueness of human experience, but may help direct us.

\section{Methods}

The preceding literature review itself is one method of answering my research questions. The books I read consolidated beliefs and values already nascent in me. Love, family, faith, communication, hope, beauty, joy and justice were repeated themes in the books I read, but experience beyond the imagined worlds of books, played the greater part in sustaining my life in education. It is to the impact of lived experience I now turn, making no apology for the interpretative nature of my research. Questions concerning feelings, attitudes and beliefs cannot be answered satisfactorily in any other way.

To discover sources and constituents of resilience, methods needed to reflect the complexity and contradictions many of my literary influences concealed. I had to interrogate multiple representations of my own life story, to compare these narratives with those of others who had preserved their ideals in education and to reflect on the impact of my lifelong interests in art, music, geography and religion. I also wanted this research to be of use in teacher education and therefore applied my findings to a wide range of teacher education contexts. This 
combination of approaches I termed Inter-disciplinary and praxis-focussed auto-ethnography for it aimed to change, generate and direct action in teaching. Below are details of the steps by which I sought to answer my questions:

\subsection{Collecting and Examining an Autobiographical Archive}

Between 2002 and 2007 I wrote six different autobiographies. They were not intentionally dissimilar. Re-reading the first months after it was written exposed many omitted details and glossed-over events, so I wrote another to fill the gaps. In 2004 and in a darker mood I generated a third autobiography, covering more sombre episodes of life. After my first grandchild's birth and the loss of another in 2005 I wrote a fourth, reassessing life in the light of their existence. I completed two abstract and less chronological autobiographical fragments in 2007. Each narrative was saved in a different colour font and used as data. During the same period I unearthed a number of youthful diaries, letters, sketchbooks, paintings and favourite music that spanned my life from pupil to teacher educator.

Written sources were combed for commonalities. Repeated words, themes and phrases were recorded. From the silent images in sketchbooks and paintings and the music I extracted a list of recurring subjects. Using a simplified grounded research technique (Glaser and Strauss, 1967) I identified themes, which were experienced within various categories and each category had certain properties (Figure 1).

I used sonata-form, a structure borrowed from music, to critique my emerging conclusions. Sonata-form presents a main subject which is then challenged by an invented counter-subject to generate a sonic 'argument' for dominance, expressed in an elaborated 'development' section. The quarrel resolves towards a recapitulation of the two themes and ends with a coda where the themes return conjoined and transfigured. I applied this structure to the themes generated by analysis of my autobiographical archive. Sonata-form facilitated the discovery of alternative interpretations, stories which contradicted and threatened to overpower the customary narrative of my life. The battle between contrasting interpretations of the same events often resulted in philosophical and emotional dissonance but sometimes harmony. Either way this systematic process of examining conclusions resulted in more profound insights and heightened awareness of the many levels of reality with which we all live. As these inner arguments were recapitulated I discovered increased confidence in some values but inconsistencies in others. I examined these in relation to work/ life decisions.

\subsection{Consulting and Critiquing a Personal Library}

My critical review of personally influential books and writers revealed other selves, unconscious themes, biases and inconsistencies, but also confirmed many fundamental beliefs, values and attitudes.

\subsection{Using the Life Narratives of Friends}

Friendship is a significant thread through my diaries, letters and autobiographies. I therefore chose successful and close friends in education (Angeles, Cherry, Danny, Grenville, Julian, Peter, Robert, Stephen and Vincent) to help in my search for the sources of resilience in teachers. This aspect of the research involved enquiry into private life, deeply held beliefs and self-criticism, and friends were an obvious choice as subjects. Easily accessible and familiar with both my public and private faces, friends also knew my hidden agendas. Often taking the role of critics, friends also tend to be less influenced by my characteristic over-enthusiasm, less likely to give me polite answers.

Permission to use real names and stories was granted by all, though references to others beyond our group were fictionalised. Several two-hour recorded biographical conversations were held with each friend, and relevant discussions, emails and texts occurred throughout the research period. Conversations were recorded, transcribed and analysed using a simple code for themes, categories and properties similar to those used for my autobiography. Transcriptions were read and re-read many times alongside the autobiographies. Re-reading my story in the light the stories of others unearthed hitherto 'forgotten' memories countering formerly 'safe' assumptions.

Friends were unfazed by personal probing and generous with time and interest They also posed problems as research subjects. Conclusions from friendly conversations may be argued to lack the rigour necessary for systematic enquiry. Friends may wish to please by providing friendly answers, or be too close to provide the triangulation of a hypothesis. The power relationships within my friendships may be too established to generate contradiction. These fears were not realised. I expected my friends to share my values, and discovered they did not. When I thought they would agree with my analyses, they came back with strident disagreements, corrections and clarifications. Through my privileged access to their minds I became powerfully aware of the infinite variation between all minds, particularly in matters concerning beliefs, values and approaches to education. Nonetheless I needed to address reliability and used the following methods to increase transparency and counter 
friends' tendency to support:

- Conversations were frequently revisited over ten years,

- Conversation transcripts were available for revision,

- Extended time (often months) was given for reflection,

- Group discussions on values, creativity and friendship were held,

- Grounded research methods were used to analyse transcripts,

- 'Sonata form' structure interrogated conclusions

- Parallel 'values conversations' were held with other educators.

\subsection{Gathering Evidence from Teacher Education Projects}

My academic writing on creativity and curriculum generated invitations to lead teacher development projects throughout the research period. Independent evaluations and course feedback provided further examples of resilience in action among successful teachers. The combined findings from autobiographical and biographical analyses, literature review and course evaluations led me towards a hypothesis expressed in the form of a diagram (Figure 2).

\section{Results}

Findings are separated under headings: autobiography, conversations with friends and evaluations from ITE projects.

\subsection{Autobiography: Identifying the Sources of Beliefs and Values}

Close examination of the autobiographies, diaries, letters and images revealed seven repeated themes: family, friends, love, emotions, religion, work and place. Each theme was subject to recurring categories of psychological and social life which were in turn sub-divided into common properties:

\begin{tabular}{|c|c|}
\hline $\begin{array}{l}\text { CATEGORIES through which I interpreted } \\
\text { the themes. }\end{array}$ & $\begin{array}{l}\text { PROPERTIES into which categories were divided (with } \\
\text { some definitions) }\end{array}$ \\
\hline \multirow[t]{3}{*}{$\begin{array}{l}\text { VALUES (deeply held beliefs that act as guides } \\
\text { to action) }\end{array}$} & $\begin{array}{l}\text { Principles (the repeated habits of mind and behaviour that } \\
\text { encapsulate our preferred values) }\end{array}$ \\
\hline & $\begin{array}{l}\text { Life long interests (a personal passion that remains with } \\
\text { an individual through all or most of their lives) }\end{array}$ \\
\hline & $\begin{array}{l}\text { Educational approaches (ways of being, relating, learning } \\
\text { and teaching in an education environment) }\end{array}$ \\
\hline \multirow{3}{*}{$\begin{array}{l}\text { BELIEFS (profoundly felt and resistant, } \\
\text { psychological conditions representing what we } \\
\text { understand to be true.) }\end{array}$} & $\begin{array}{l}\text { Attitudes (mental responses that imbue certain thoughts, } \\
\text { actions, people or events with favour or disfavour.) }\end{array}$ \\
\hline & Religious faith \\
\hline & Secular faith \\
\hline \multirow{3}{*}{$\begin{array}{l}\text { KEY STORIES (stories that explain the } \\
\text { sources or expression of personal values, } \\
\text { principles or lifelong interests.) }\end{array}$} & Significant relationships \\
\hline & Significant places \\
\hline & Significant events \\
\hline \multirow{6}{*}{$\begin{array}{l}\text { KEY PEOPLE (those that help shape life's } \\
\text { experiences and influence beliefs, attitudes and } \\
\text { values) }\end{array}$} & Friends \\
\hline & Family \\
\hline & Inspirers \\
\hline & Negators \\
\hline & Mentors \\
\hline & Groups \\
\hline \multirow[t]{2}{*}{ KEY CONCEPTS } & $\begin{array}{l}\text { Positivity (thoughts and behaviours that generate pleasant } \\
\text { feelings and bring benefits to self and community) }\end{array}$ \\
\hline & Negativity \\
\hline
\end{tabular}


Creativity (the ability imaginatively, socially or practically to put two or more concepts, ideas, materials or things together to make a valued new one.)

\section{Affirmation}

Well-being (the perception of a state of psychological, social, spiritual and physical health)

Figure 1. Categories and properties arising from the examination of autobiography and biographical conversations

From analysis of these themes, categories and properties it emerged that values, creativity and friendship did most to create feelings of resilience.

\subsubsection{The Role of Feelings and Values}

Feelings and beliefs dominate diaries, surviving letters and autobiographies covering my late teens. Beliefs became the roots of some lifelong values; feelings created and fed them. Damasio (2003, 2012) provides a helpful distinction between feelings and emotions. Feelings are self-conscious perceptions of inner, private mental/physical sensations, which resist accurate verbalisation but are often represented in a particular negative, neutral or positive bodily state. Emotions are shared by humans and other animals and are the outward, simpler manifestations of feelings.

Values also involve feelings. Booth (2010) defines values as: 'Fundamental guides and prompts to action.' I use the term 'virtuous values' to denote those seen across time and many cultures as being morally 'good', affirming and sensitive to the needs of individuals and community. In word counts and described feelings, virtuous values heavily outweigh negative factors in all written narratives of my teenage life. Analysis of diaries, letters and autobiographies, suggested I was guided by following feelings and beliefs:

- I was loved and could love (there were also times when I did not believe this).

- Communication across cultures is good and possible (fascination with my Caribbean neighbours is an early memory, it generated my desire to work abroad, befriend people from other cultures and work with the deprived, but also masked unwitting racism).

- Wordless aspects of life are amongst the most meaningful, (expressed in my early love of painting, drawing, music and ceremony, but contradicted by a lack of unequivocal commitment to any one of them).

- Places are powerful influences and can confer a sense of belonging, (happy early memories of the outdoors and impressive interiors did not always translate into environmental sensitivity).

- $\quad$ There is purpose to life, (affirmative experience of religion led me to expect spiritual meaning in events and relationships, later life experience challenged this belief).

These feelings spawned attitudes frequently woven into my self-told story. Positive stances towards family, religion, people, places and the arts clearly influenced life decisions and some would argue provided the 'cultural capital' to fund the upward social mobility I experienced (Bourdieu, 1993). Feelings and non-virtuous values also drove the exclusions, over-confidence and post-colonial attitudes glossed over in my first two autobiographies.

\subsubsection{Key Stories}

In memory and conversation the haphazard events of life are linked for me by a series of Key Stories. These succinct, flowing, repeated and free-standing narratives cover often 'minor' incidents that exerted transformative effects on life. Attempting to verify these stories, with visits, through diaries, letters and the memories of others, I found details often mis-remembered in my enthusiasm for a good story. These stories, felt long before translated into words, have symbolic value; their meaning is more important than factual content. Values like love, generosity; honesty, kindness, faith, joy and hope are captured from life and fashioned into short narratives that shape my mind, explaining it to myself and others. Observing these values in the actions of others continues to provoke my tears and each constituent of my 'framework of values' (Booth, 2010), sustains me, but only when given a means of expression. Key stories reassert values when doubted, cement, signify and deepen friendships and communicate my priorities.

One memory of a moment when I was twelve year old choirboy, illustrates the power of key stories 
1963 ...we stood, all robed up in stiff ruffs, trailing white surplices and red cassocks, in an ambulatory towards the east end of the cathedral waiting for the sign to process into the choir. We gathered each day at the foot of the extraordinary shrouded and slightly sardonic monument to John Donne...In this quiet and secret corner of an awesome building, illuminated from my left by strong, golden, stained-glass light, I heard for the first time the thunderous organ music of Messaien and Bach, the combined experience of monument, light, ceremony and monumental sound transported me very powerfully beyond myself to a kind of heaven. (Autobiography, March 2002)

The child-led, cross-curricular, arts-based and creative approaches with which I identify, stem directly from this event even though many other incidents probably contributed.

Stories from later life often come from exotic surroundings. Teaching and travelling abroad, first in Kenya, later in Malaysia, India and Tanzania, played an important part in transforming beliefs and attitudes into life-directing values like tolerance, patience and sensitivity. One momentary encounter exemplifies the effect of positive communication across cultural boundaries:

1982 One day walking between the rice fields with my... 5 year old..., who had committed some minor misdemeanour, a stranger, ... came the other way towards us from a temple in the forest. He stopped when we came near, looked smilingly into my face and simply said 'You must never be angry with your child on Bali, he is the nearest thing we have to God.' Such a gentle ... upbraiding instantly chastened me and in many ways this young man whom I never met again, nor knew his name, has influenced me profoundly ever since...(Autobiography, March 2002)

Values were also conflicted, compromised and assaulted. Another key story referring to my time as a head teacher captures one such attack:

1995. A local authority education advisor came ... to see the projections of [SATs] scores... she asked why one five year old child was projected only a level three in English by the time he would be eleven [level four was considered the average] ... I answered that he had suffered a family break-up that year and I saw it taking two or three years to get even partly over the trauma .... The education official tried to persuade me to raise predictions for that child and I refused.... she then questioned my liberal, thematic and cross curriculum, suggesting that it was 'dangerous' ... that it would be safer to leave the creative and imaginative curriculum until after my school had received SATS results well-above expectations. (Autobiography, 2005)

Negative happenings can kill or strengthen values. The story above led me to leave school headship and seek work in ITE where I could further my interests in an involving, sensitising and liberating curriculum for children ill-served by education policies.

\subsection{Friends' Biographies: Corroborating Values, the Value of Friendship and Importance of Creativity}

Conversations with friends in education focussed on their beliefs, values, passions and attitudes. These intimate exchanges generated findings that challenged the conclusions of my auto-ethnography. Commonalities and contradictions appeared in the accounts of friends and are summarised below:

\subsubsection{Commonalities}

- Values form early in life - most identified the roots of core values in childhood,

- Values are often expressed in key stories,

- Articulating and discussing values is unusual but valuable,

- Family values often outweigh other values,

- Friendship includes the temporary accommodation of another's values in dialogue or shared projects,

- Friendship involves upholding, repairing or reinforcing the others' core values.

- We act out cherished values in lifelong interests,

- Creative expression of values gives great satisfaction

What became known as 'values discussions,' enriched and deepened our friendships, reinforced existing values, in each of us increased values-sensitivity and made us feel good. They also revealed differences.

\subsubsection{Contradictions}

Agreeing on specific values proved difficult. In two focus groups friends established generalised agreement on the special place of 'virtues' like honesty, courage, love, generosity, compassion and justice, but personally 
stated values such as: environmental sensitivity, creativity and cohesive communities provoked disagreement. Discussion suggested that values:

- Do not always result in action,

- Are not defined in the same ways,

- Are rarely fully understood by others,

- May not include creativity,

- Can be independent of support,

- Are sometimes in opposition to each other.

Such incongruity with my own views supported my claim that friends could be more likely to resist the tendency to agree with the researcher.

\subsubsection{Life-long interests and values}

Friend Julian's key story links a love of music with his core value for supportive community:

I take it right back to being a chorister and to being very excited by being part of a much larger whole $\cdots . \cdots$ and I did that at $8 \cdots$ it was a real milestone because I knew I wanted to do it. On its own music, it's sort of nothing without the other parts and the organ and the occasion...You couldn't go upstairs and sit in the choir stalls and produce something second rate...Here we were in the cathedral and there was this sense of having to be the best and as a small child that's what you believe (J.Con.1:7)

Similarly, Cherry spoke of her passion for art and music arising from brass rubbing in churches alongside her dad. In adulthood she uses her artistic skills to express and develop her deeper concern for the well-being of children. She says her skills help her:

-.use art and music as ways into learning '.my pottery and my teaching are both complementary parts of my life, the public and the creative ...this makes a positive difference to children and stops me being pushed around by people or legislation, '(C.Con.1: 2).

For some, affirmations, (large in childhood and often quite small in adulthood), keep passions alive and refresh the values they embody.

\subsubsection{Values and Affirmations}

Stephen raised the subject of values being nourished by affirmations. Subsequent re-readings of autobiographies and conversations unearthed many occasions where praise had been transformative. Justified, focussed and acceptable affirmation from teachers, family or friends was particularly influential. Julian spoke of being, 'flattered to death' by one teacher's response to his musical compositions, Danny of his pleasure in being told he had, 'a talent for art' and many others agreed on the disproportionate effect of such praise when delivered by revered individuals. Angeles even related the affirmation emanating from a place - her primary school:

...more beautiful than my house, so calm an environment, garden rooms with wonderful opening windows and good paintwork,... (A, Con. 1.7)

\subsubsection{Inspirational People and Sustaining Ideals}

Friends and I effortlessly identified those who had breathed new life into the things we cared most about. Vincent, for example, remembered nuns visiting his grandfather's 'religious items' shop in south India when he was young. His words capture the genesis of the idealistic and practical mindset that now underpins his fulfillment in working with 'the poorest of the poor':

I saw a lot of dedicated people there doing service for others without any expectations. I thought for some time I should like to join them in their work, I was about 12/13 years old at the time. (V.Con.1:2)

Familiarity with such personal key stories is perhaps a measure of friendship, but relating them also elevates the teller, underlining what makes their lives distinctive and sustaining them.

\subsubsection{Friendship, Values and Resilience}

Values conversations deepened friendships and bolstered beliefs. Whilst agreement on values was difficult, friends often described 'a temporary accommodation,' (Danny's words) of the other's values when engaged in joint projects or discussions. Ventures involving individual friends and myself, almost always concerned mutual passions for music, art, language, environment or pedagogy. During these activities friends described themselves 
in phrases like: 'most myself', 'most human', 'in the right place', 'at my best' or 'genuinely fulfilled'. In discussion friends described collaborative projects in line with their values as 'affirming' and 'deeply satisfying'.

\subsubsection{Creativity and Resilience}

Friends were highly aware of their creative strengths. The exercise of signature areas of creativity generated feelings of fulfillment, and when their creativity was inhibited friends unanimously described themselves as unhappy. In discussion we agreed that values and creative strengths often overlapped. When values and lifelong interests were allowed or encouraged in our work we found the strength to counter setbacks and carry on. Grenville, Peter, Vincent and Julian's love of composing and collaborative music-making for example, expressed more fundamental beliefs in the importance of caring communities. Danny's high value for compassion shows in his painting and articulate conversation, Angeles' value of fairness is played out in her inclusive, inventive, humorous teaching style and Robert's concern for social justice is evident in his teaching, acting, directing and creative leadership of social action. Stephen's passion for the truth is fundamental to his creative geography teaching and writing and love imbues both Cherry's imaginative work with disadvantaged children and the shaping of her pottery. When values were compromised all looked to former creative achievements for encouragement.

\subsection{Teacher Education: Putting Research into Action}

Research changed my practice. Teacher education provided opportunities to test my findings. I have selected four from 40 projects that explored values, creativity and friendship to illustrate research turned to action:

- The HEARTS ITE project 2003-2005, (NFER, 2006; Barnes 2013c)

- The Teach for Malaysia (TFM) Creativity ITE module 2012, (TFM website, Pitchin website)

- The Creative Leadership project for head teachers, (Dismore, et.al, 2008)

- The Creative Teaching for Tomorrow (CTT) study, (Cremin, Scoffham and Barnes, 2009).

Each began with guided personal reflection followed by conversation, then lengthy discussion on personal values. Each moved towards the establishment of agreed sets of values. Evaluations showed both novice and seasoned teachers found values discussion novel, but greatly appreciated. 'Great to spend time, at last (!) taking about what we went into teaching for,' (Dismore, et al.2008 p.2) was typical of evaluative comments. The reflective opening of each project resulted in further commonalities.

\subsubsection{Deepened Relationships}

The projects had a visible influence on relationships. After the relative intimacy of paired conversations on personal values, faces and body language relaxed, became more open and inclusive. After the values discussions each course was punctuated by a range of practical, open-ended, group exercises designed to provoke collaboration and sensory/emotional interaction between participants within a stimulating environment landscape, townscape, museum, gallery (summarised in Scoffham, 2013). Evaluations provoked the words 'friends' or 'friendly' in over $76 \%$ of responses.

\subsubsection{Lifelong Interests}

Participants were also asked to reflect on personal passions. They were encouraged to bring approaches and knowledge from lifelong interests and use features of the immediate environment, to address a particular learning objective. In the TFM project, students used their enthusiasms and values coupled with tiny details of their modern university campus to teach discrete aspects of geography, history, grammar, science or mathematics curriculum. The use of personally significant starting points powerfully motivated individuals and was measurable in increased signs of engagement and well-being amongst students. Both the CTT study and the Creative Leadership project showed that educators interpreted such attention to their personal interests as 'nurturing'.

\subsubsection{Creativity}

The projects predictably elicited positive comments on creativity, but follow-up questionnaires related to the HEARTS project (Barnes 2013b in press) found that participants continued to name and champion creative teaching approaches five years later. Participants from each course said they recognised their creative strengths 'for the first time', one tweet from a TFM participant called the project a 'turning point in my professional life,' (personal communication 14/12/1/2). School leaders on the Creative Leadership course pinpointed empathy, connection, collaboration, risk and confidence as constituent aspects of their new understanding of creativity (Dismore, et al.2008). 


\section{Discussion}

My friends do not represent all teachers. Friends usually share similar beliefs, interests and values despite differences in definition. Not all members of my ITE or PPD courses found satisfaction in creative activity or sought to discover creativity in themselves, some were reluctant to share personal narratives. Yet I claim the findings of my research have significance. Friends' and my own narratives and the large majority of course evaluations highlight commonalities that relate to resilience and link this to effectiveness within teaching. The experience of putting my research into action has generated theory that maintains: attention to values, personal passions, creativity and friendship throughout teacher education helps develop resilience, builds capacity and that these benefits are passed onto children in more effective teaching. These claims are discussed below under the following headings:

- Values and resilience

- Creativity and meaning

- Friendship and community

- Teacher education and children

\subsection{Values and Resilience}

Findings suggested that in work-life characteristics of resilience like hopefulness, fulfillment and joy arise from times when professional and personal values match (see also, Whitehead, 2006; Whitehead and McNiff, 2009). Research subjects quickly and succinctly articulated their core values on request despite remarking on the unusualness of the question. All provided narrative evidence that personal values were expressed through their teaching and believed this made a positive difference to children. Each recounted similar idealistic aspirations, 'to make a positive difference' in ITE and job interviews, though on reflection most admitted teaching was a second or third-choice career, but that a life in education itself had taken them further towards their ideals. These were surprising unanimities. Common to all were remembered instances where children's positive responses had empowered them to bounce back from difficult times. Resilience also involved perceptions that personal values could be creatively played-out in the classroom and that ideals were appreciated and shared.

I characterise the creativity and well-being-focussed teaching approaches so far described as 'Positive Pedagogy,' (Scoffham and Barnes, 2011). The satisfaction of having personal passions validated and developed, sustained me and my research subjects through difficult times. Analysis of ITE and PPD course evaluations further confirmed the importance of unique, positive narratives - key stories- in maintaining a meaningful life in education but also suggested that resilience was related to:

- Opportunities regularly to discuss values,

- Opportunities to express cherished values through lifelong interests,

- Frequent occasions to develop personal and collaborative creativity,

- Inclusive, warm and friendly relationships.

These observations indicate an agenda for teacher education, but the low priority in ITE and PPD of values-literacy, creativity and friendship mean that few are offered their sustaining effects. Teacher resilience is clearly a vital personal and professional resource. Positive long-serving teachers are likely to promote happy classes, and happy children learn better. Whilst some suggest rote learning, discipline and ease with 'the basics' are the first priorities for education, research backed-up by continuing experience suggests that values-literacy and discipline, creative opportunities and facts, friendship and respect are characteristics of successful and fulfilled teachers and learners. Teacher development programmes should therefore strive to combine rigour and freedom, fact and fantasy, personal and professional. From my evidence, personal stories and activities related to values, lifelong interests, relationships and creative strengths do not simply enliven education, they make it relevant, meaningful and motivating for most. I claim that such humanising pursuits are sustaining and build capacity and raise standards.

\subsection{Creativity and Meaning}

Friends found meaning in creative acts (see Csikszentmihalyi, 1997). Peter expressed it this way:

...when you make something that is yours and you've done it, whatever it is - whether it's a clay pot or a piece of music or a fantastic composition or a pile of bricks I think it's just hugely enjoyable to do and you realise that you've done it and no-one else has done it and it's unique to you even if it's a copy of something else - it's still unique .... (P Con. 1:10) 
Image, music, poetry, gesture, architecture, place and relationship, connect to something bigger than and beyond self. My joy, once experienced in singing in a cathedral choir, is now expressed in writing and teaching on cross-curricular learning (Barnes, 2011, 2013a, 2013b). I found that the autonomy, uniqueness and purpose generated by teaching within one's core value-set was essential to the happiness of just ten teachers These perceptions match wider research on well-being (e.g. Ryff; 1989 Bandura, 1997), but my study also shows that for many teachers, awareness that others benefit from our fulfillment, is sustaining.

Interviews and self-analysis confirmed Adler's (1964) suggestion that we feel fully alive and capable of growth, new learning, new relationships, when engrossed in our creative strengths (see also Csikszentmihalyi, 2002; Fredrickson, 2009). Friends claimed that the meaning generated by working with chosen interests, imbued professional and personal life equally. Some (see, Hirsch, 1989; Furedi, 2009; Ecclestone and Hayes, 2009; Wilshaw, 2012) see applying such attitudes to teaching as dangerously therapeutic, impractical and endangering teachers' knowledge-imparting, standards-raising role. These critics must show how they would rebuild crumbling life and job satisfaction in a profession constantly under fire and serving increasingly diverse, rapidly changing, hard-to-reach and often creatively/culturally impoverished communities. Looking back to their own childhood each research subject identified effective and memorable teachers who shared the joy of their own lifelong interests. These teacher-founders of our present resilience effectively linked teaching and learning with virtuous-values, personal creativity and warm relationships. All pupils should have access to such inspirational figures.

\subsection{Friendship and Community}

Enduring relationships are crucial to personal well-being and the sustainability of communities, (Wenger, 1998; Noddings, 2003; Pahl, 2006, Bonn, 2012). Like friendships, good communities involve mutual affirmation and the overlap of values. Friendships and communities grow from shared, active situations where people support each other in addressing genuine challenges. Joint undertakings when seen as relevant and worthy, frequently generate the condition Csikszentmihalyi (2002) describes as 'flow'. In this psychological state of total engagement, time and self-consciousness seem to disappear; we are more relaxed, receptive, open to new relationships and confident. Such feelings occur individually during much-loved practical, physical, reflective or creative activities, but they can also be an aim of school curricula. Teachers and others committed to children's well-being should consider beginning curriculum plans by identifying activities most likely to result in flow experiences. A string of such experiences offer the benefits of promoting motivation and learning through positive self-image and constructive relationships. (Barnes 2013b).

Family and cultural settings should generate positivity and supportive friendships, but not all do. Schools are the only institutions able to offer these opportunities to all children. Thousands of school prospectuses express aspirations to nurture socially and psychologically healthy children and values-led communities - but it is questionable whether teacher education currently develops the beliefs, attitudes and curricula to achieve such aims.

\subsection{Teacher Education and Children}

Results from PPD projects strengthened my belief in the power of teacher education to affect children's lives. They showed that emphasis on values, personal strengths, creativity and friendship generated sustainable change in a wide range of educational settings, (e.g., Barnes and Shirley, 2007). Contributions from neuroscience and psychology add weight to my argument that teacher education must change if we are positively to affect the resilience of teachers.

New knowledge about learning (LeDoux, 1999, 2002; Immordino-Yang and Damasio, 2007; Goswami, et al, 2007; Geake, 2009; Alexander 2010; Rowson and McGilchrist, 2013) has established that emotional and sensory engagement, joy, hope and social interaction provide optimal conditions for lasting, transferable learning. Such findings challenge prevailing political trends towards increased competition, compliance, costing and counting. Contrary to research evidence 'soft' skills like creative thinking, collaboration, emotional intelligence, community building and environmental sensitivity have been marginalised in the primary national curriculum for England (DfE, 2013). Whilst many governments stress testing and a narrowed curriculum, neuroscientific research suggests greater attention is paid to developing breadth, flexibility, innovation, joy, collaboration and resilience.

Advances in the science of learning should engender debate within the education community. It is surprising therefore, that ITE institutions are so slow in including neuroscience modules in their courses and that PPD has generally avoided approaches personally meaningful to child or teacher. Critics of educational neuroscience highlight the dangers of reductive and half-understood interpretations, but these fears apply equally to 
pedagogical, psychological and sociological insights, long part of teacher education. Perhaps the relative novelty of neuroscience explains its low profile in ITE, but neuroscientific perspectives increasingly inform cultural, business and political decisions. Real dangers result from the unsubstantiated application of neuroscience to education, (see Geake, 2009) but unless teachers engage with neuroscience, political and commercial interests outside education will use it to further their aims.

My research links ten teachers' sense of a fulfilling life in education to their ability to maintain positive self-told narratives involving personal values, enduring relationships, lifelong interests and creativity. When their stories are combined with wider research on fulfillment, learning and creativity, the implications for teacher education and children become clear. If teachers' happiness were a substantial focus of their education, my evidence suggests that benefits would rapidly transfer to the children in their care, establishing the virtuous circle illustrated below.

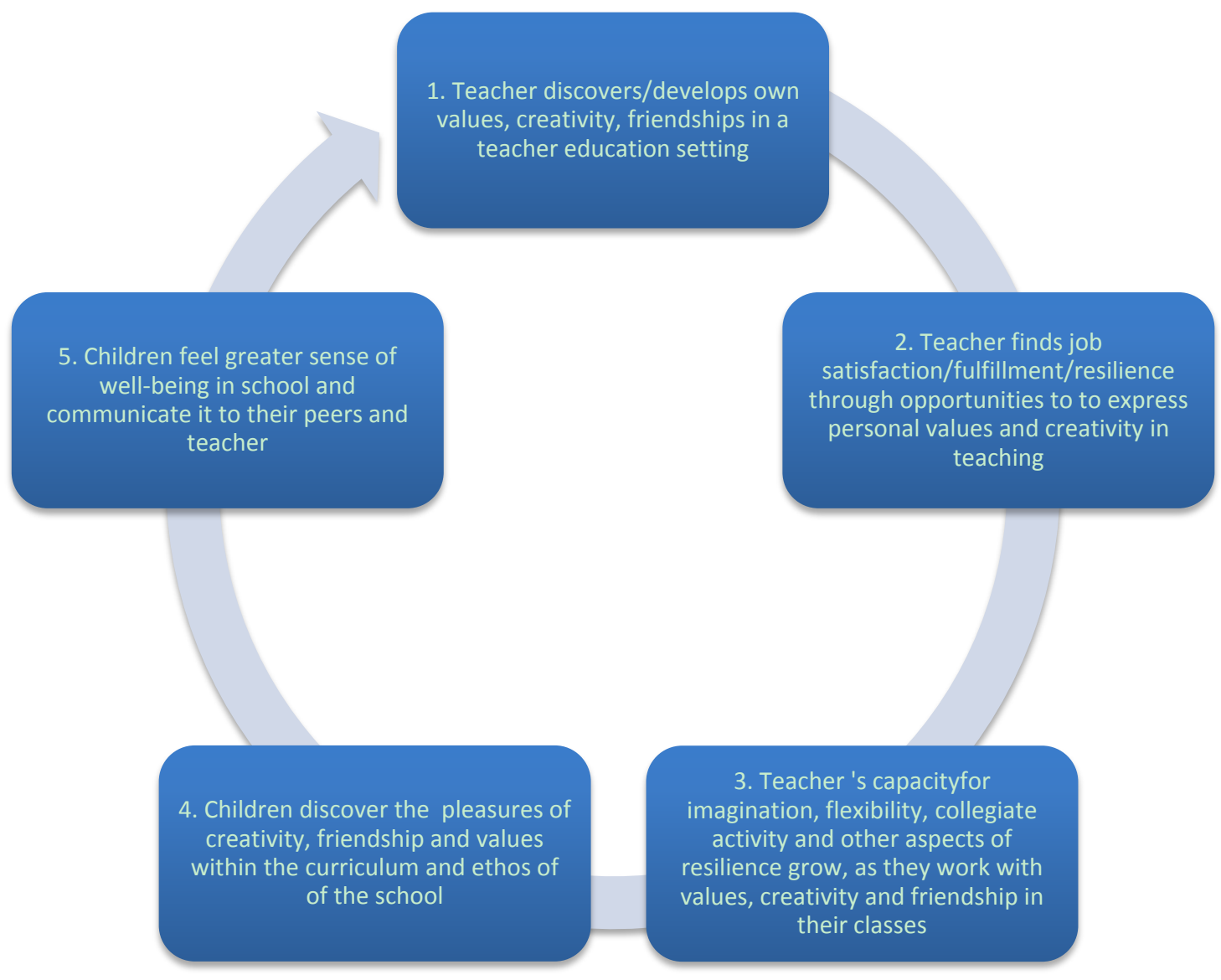

Figure 2. Teacher resilience powers a virtuous circle leading to child well-being greater job satisfaction for teachers

\section{Conclusions}

Whilst I sought and found answers to my research questions there are shortcomings inherent in its personal nature. This is clearly a pilot study aimed at identifying focal points for further study. The findings are therefore fully open to contest or verification. The sources of values are likely to be much wider spread than I have indicated and the relationship between values and resilience is more complex than I suggest. Despite ten years of research I did not sufficiently allow for changed stories, negative or lost values, sources of resilience outside those raised by my research subjects. I gather little quantitative evidence. Research in these areas would enhance the debate. However, extensive trialing of my research findings and the warm feedback it has received, gives confidence to argue that my conclusions need further study in the real-life settings of pre-schools, schools, colleges and universities and in the context of preventative social and psychological health. If resilience is related to congruence between personal and institutional values, if supportive and flexible environments nurture resilience and if resilience grows by identifying and extending our creative strengths, teacher education should be founded upon these things. Teachers remain the most important resource for the education of children. I 
believe a teacher education in which teachers' own well-being was central, would lower stress levels and empower teachers to provide a psychological, social and curricular school environment in which every child can improve their resilience via significantly increased encounters with life-enhancing moments.

\section{Acknowledgements}

I am grateful to the Sidney de Haan Centre for Research in the Arts and Health, in granting time, resources and inspiration to write this digest of my $\mathrm{PhD}$ thesis.

\section{References}

Achebe, C. (1957) Things Fall Apart, London, England: Heinemann.

Adler, A. (1964). The Individual Psychology of Alfred Adler. Ansbacher, H. \& Ansbacher, R. (Eds.). New York, NY: Harper Torchbooks

Alexander, R. (ed) (2010). Children, Their World, Their Education: Report of the Cambridge Primary Review, London, England: Routledge.

Bandura, E. (1997). Self-Efficacy: the exercise of control, New York, NY: Worth

Barnes, J. (2011). Cross Curricular Learning 3 - 14 (Second Edition), London, England: Sage

Barnes, J. (2013a). 'Drama to Promote social and psychological well-being in six and seven year olds with speech and communication difficulties: The Speech Bubbles project', Perspectives in Public Health.

Barnes, J. (2013b). HEARTS five years later, Improving Schools, in press.

Barnes, J., \& Shirley, I. (2007). Strangely familiar: Cross-curricular and creative thinking in Teacher Education, Improving Schools, 10(2), 289-306.

Barnes, J., \& Scoffham, S. (2013). 'Creativity, place and the future' in Scoffham, S. (Ed.) Teaching Geography Creatively, London, England: Routledge.

Beard, R. (1969). An Outline of Piaget's Developmental Psychology for Students and Teachers. London, England: Routledge \& Kegan Paul.

Berger, P., \& Luckman. (1967). The Social Construction of Reality: A treatise on the Sociology of Knowledge, New York, NY: Anchor.

Bonn, G. (2012). The Structure of Cultural Orientations to the Good Life and their Expression in Personal Narratives, University of Toronto $\mathrm{PhD}$ thesis.

Booth, T. (2005). 'Keeping the Future Alive: Putting inclusive values into action. FORUM, 47(2 \& 3), 151-157.

Booth, T., \& Dyssegaard, B. (2009). Quality is not Enough: A Discussion Paper. http://www.eenet.org.uk/resources/docs/QualityIsNotEnough.pdf

Booth, T. (2010, June11). 'How Should we Live Together? Inclusion as a framework of values for educational development', Keynote Lecture, Berlin, Dokumentation Internationale Fachtagung.

Bourdieu, P. (trans.1993). The Field of Cultural Production, Cambridge, England: Polity.

Bowlby, J. (1958). Childcare \& the Growth of Love, London, England: Pelican.

Bowlby, J. (1988). A Secure Base: Clinical Applications of Attachment Theory, London, England: Routledge.

Bruner, J. (1968). Towards a Theory of Instruction, New York, NY: Norton.

Buber, M. (1971). I \& Thou, New York, NY: Free Press.

Cremin, T., Scoffham, S., \& Barnes, J. (2009). Creative Teaching for Tomorrow, Deal, England: Future Creative.

Csikszentmihalyi, M. (1997). Creativity: Flow and the Psychology of Discovery and Invention, New York, NY: HarperCollins.

Csikszentmihalyi, M. (2002). Flow: The Classic Work on How to Achieve Happiness, New York, NY: Ebury Press.

Damasio, A. (2012). Self Comes to Mind: Constructing the Conscious Brain, London, England: Vintage.

Damasio, A. (2003). Looking for Spinoza: Joy, Sorrow \& the Feeling Brain, Orlando, FL: Harcourt.

Dewey, J. (1934). Art as Experience. Reprint. New York, NY: Wideview/Perigree. 
Department for Education, UK. (2012). Standards for Qualified Teacher Status, https://www.education.gov.uk/publications/eOrderingDownload/teachers\%20standards.pdf

Dismore, H., Barnes, J., \& Scoffham, S. (2008). Space to Reflect, London, England: Creative Partnerships.

Ecclestone, K., \& Hayes, D. (2009). The Dangerous Rise of Therapeutic Education, London, England: Sage.

Ekman, P. (2004). Emotions Revealed: Understanding Faces and Feelings, New York, NY: Phoenix.

Entwistle, N. (2000, November 11). 'Promoting deep learning through teaching \& assessment: conceptual frameworks \& educational contexts', paper presented at Teaching \& Learning Research Programme (TLRP) conference, Leicester.

Frankl, V. (1959). Man's Search for Meaning, Boston, MA: Beacon Press.

Fredrickson, B. (2004). The Broaden \& Build Theory of Positive Emotions, Philosophical Transactions of the Royal Society: Biological Sciences, 359(1449), 1367-77. http://dx.doi.org/10.1098/rstb.2004.1512

Fredrickson, B. (2009) Positivity, New York, NY: Crown.

Freud, S. (trans. Strachey, J.) (1961). Civilization \& its Discontents, London, England: Norton.

Friere, P. (1970). The Pedagogy of Hope: Reliving the Pedagogy of the Oppressed, New York, NY: Continuum.

Fromm, E. (1956). The Art of Loving, New York, NY: Harper.

Furedi, F. (2009). Wasted: Why Education isn't Educating, London, England: Continuum.

Gardner, H. (1993). Frames of Mind: The Theory of Multiple Intelligences, 2nd edn, London, England: Fontana.

Geake, J. (2009). The Brain at School, Educational neuroscience in the classroom, Maidenhead, England: Open University Press.

Glaser, B., \& Strauss, A. (1967). The Discovery of Grounded Theory: Strategies for Qualitative Research, New York, NY: Aldine.

Goswami, U., \& Bryant, P. (2007) Children's Cognitive Development and Learning, Primary Review Research Briefings 2/1, Cambridge, England: University of Cambridge Faculty of Education

Guardian. (2010, November 16). Why are new teachers leaving in droves? http://www.guardian.co.uk/education/2010/nov/16/teaching-problem-schools

Guardian. (2012, June 11). Newly Qualified Teachers being hounded out by bullying schools. http://www.guardian.co.uk/education/2012/jun/11/newly-qualified-teachers-unsupported-leaving

Health and Safety Executive (UK) http://www.hse.gov.uk/statistics/causdis/stress/stress.pdf

Hicks, D. (2006). Lessons for the Future: The Missing Dimension in Education, London, England: Routledge.

Hirsch, E. (1989). The Schools we need \& why we don't have them, New York, NY: Anchor Books.

Illich, I. (1971). Deschooling Society, London, England: Calder \& Boyars.

Immordino-Yang, M., \& Damasio, A. (2007) We Feel Therefore We Learn: the relevance of affective \& social neuroscience to education. Brain, Mind \& Education, 1(1), 3-10.

Independent on Sunday. (2012, May 27). Teacher exodus as thousands go for early exit, http://www.independent.co.uk/news/education/education-news/teacher-exodus-as-thousands-go-for-early-e xit-7791466.html

Isaacs, S. (1932). The children we teach: seven to eleven years, London, England: University of London Press.

Jung, C. (1963). Memories Dreams and Reflections, London, England: Vintage.

LeDoux, J. (1999). The Emotional Brain, London, England; Phoenix.

LeDoux, J. (2002). The Synaptic Self, New York, NY: Viking.

McNiff website, available at: http://www.jeanmcniff.com/items.asp?id=37

Metlife. (2013). The American Teacher; Challenges for school leadership, New York, NY: Metlife, https://www.metlife.com/assets/cao/foundation/MetLife-Teacher-Survey-2012.pdf

Montessori, M. (1967). The Discovery of the Child, New York, NY: Ballentine.

Neill, A. (1970). Summerhill- A Radical Approach to Education, London, England: Pelican.

NFER. (2006). Higher Education Arts and Schools: An Experiment in Educating Teachers, London, England: 
NFER.

Ngugi, J. (1967). A Grain of Wheat, London, England: Heinemann.

Noddings, N. (2003). Happiness and Education, Cambridge, England: Cambridge University Press.

Nyerere, J. (1971). Ujamaa: essays on Socialism, Oxford, England: Oxford University Press.

Pahl, R. (2000). On Friendship, Cambridge, England: Polity Press.

Pitchin website. (2013). http://pitchin.my/project/20 and http://www.youtube.com/watch?v=8UJ641ecqqQ

Plowden, Lady B. (1967). Children and their Primary Schools, London, England: HMSO, http://www.educationengland.org.uk/documents/plowden/

Polanyi, M. (1967). The Tacit Dimension. New York, NY: Doubleday \& Co.

Price, C. (2010). 'Arts and Minds', course evaluation for Leeds Children's Services, Leeds, England: Artforms.

Rowson, J., \& McGilcrest, I. (2013). Divided Brain, Divided World: Why the Best of us struggles to be heard, London, $\quad$ England: $\quad$ Royal Society of http://www.thersa.org/_data/assets/pdf_file/0019/1016083/RSA-Divided-Brain-Divided-World.PDF

Robinson, K. (1999). (ed) All Our Futures: Creativity, Culture and Education, London, England: DfES/DCMS.

Rogers, C. (1967). On Becoming a Person: A Therapists view of psychotherapy, London, England: Constable.

Rose, J. (2009). Independent Review of the Primary Curriculum, London, England: DCSF.

Ryff, C. (1989). Happiness is Everything or Is It? Explorations on the meaning of psychological well-being. Journal of Personality Social Psychology, 57(6), 1089-1081

Schore, A. (2003). 'The Seventh Annual John Bowlby Memorial Lecture,' in Corrigall, J. and Wilkenson, H. (Eds) Revolutionary Connections, London, England: Karnac.

Scoffham, S., \& Barnes, J. (2011). Happiness Matters: Towards a Pedagogy of Happiness \& Well-Being, Curriculum Journal, 22(4), 535-548.

Scoffham, S. (2010). The Primary Geography Handbook, Sheffield, England: Geography Association.

Scoffham, S. (2013). Teaching Geography Creatively, London, England: Routledge.

Seligman, M. (2004). Authentic Happiness, New York, NY: Basic Books.

Sternberg, R. (1997). Successful Intelligence, New York, NY: Plume.

Sternberg, R. (Ed.) (1999). Handbook of Creativity, Cambridge, England: Cambridge University Press.

Teilhard de Chardin, P. (1959). The Phenomenon of Man, New York, NY: Harper and Row.

Tolstoy, L. (1966). Resurrection, London, England: Penguin Classics.

Turnbull, C. (1972). The Mountain People. New York, NY: Simon \& Schuster.

Teach For Malaysia (TFM). http://www.teachformalaysia.org

Vygotsky, L. (1962). Mind in society; the development of Higher Psychological processes, Boston, MA: Harvard University Press.

Wenger, E. (1999). Communities of Practice: Learning, Meaning \& Identity, Cambridge, Engalnd: Cambridge University Press.

Whitehead, J., \& McNiff, J. (2009). You and Your Action Research Project, London, England: Routledge.

Wilshaw, M. (2012, May 10). Speech at Brighton College Education Conference. http://www.ofsted.gov.uk/resources/brighton-college-education-conference-speech

Whitehead J. (2006). Action Research Living Theory, London, England: Sage.

Wrigley, T. (2005). Schools of Hope: A New Agenda for School Improvement, Stoke-on-Trent: Trentham.

\section{(c)) EY}

This work is licensed under a Creative Commons Attribution 3.0 License. 